\title{
REPRESENTASI GENERASI Z PADA NOVEL TAMAN SUNYI SEKALA KARYA AIDA VYASA
}

\author{
${ }^{1}$ hidyati harfin, ${ }^{2}$ amal akbar \\ Program Studi Pendidikan Bahasa dan Sastra Indonesia \\ Fakultas Keguruan dan IImu Pendidikan \\ Universitas Muhammadiyah Makassar
}

\author{
1'hidayatiharfin3@gmail.com, ${ }^{2}$ amal.akbar@unismuh.ac.id
}

\begin{abstract}
Abstrak: Penelitian ini bertujuan untuk mendeskripsikan representasi generasi Z yang terdapat dalam novel Taman Sunyi Sekala Karya Aida Vyasa. Jenis penelitian ini merupakan penelitian deskriptif kualitatif dengan metode kajian pustaka. Data yang diperoleh dari penelitian ini menghasilkan tiga bagian karakteristik dari generasi Z dalam novel Taman Sunyi Sekala Karya Aida Vyasa, yaitu fasih teknologi, sosial, dan multitasking. Dari ketiga bagian tersebut, penulis memilahmilah untuk memudahkan peneliti mengetahui pembagian ketiga tersebut di atas.

Berdasarkan hasil analisis di atas dapat disimpulkan bahwa novel Taman Sunyi Sekala Karya Aida Vyasa mengandung karakteristik generasi Z yang terdiri atas fasih teknologi membahas tentang pada zaman ini semua kalangan manusia baik anak-anak, dewasa, maupun orang tua semua sudah dapat menggunakan teknologi informasi tanpa memerlukan pelatihan khusus. Mulai dari mengutak-atik fasilitas atau aplikasi yang ada dalam teknologi serta menggunakan di jejaring sosial untuk berkomunikasi dengan orang banyak. Sosial membahas tentang bahwa tidak hanya di dunia nyata orang dapat berkomunikasi atau berinteraksi kepada khalayak unum, baik itu yang lebih muda maupun yang lebih tua dari berbagai lintasan daerah, lintasan negara dan penjuru dunia, tanpa harus bertatapan muka atau saling bertemu satu sama lain hanya melalui jejaring sosial. Dan multitasking membahas mengenai orang generasi $Z$ juga dapat melakukan berbagai kegiatan aktivitas dalam waktu yang bersamaan, mereka bisa berbicara, menonton, membaca, dan mendengarkan musik dalam waktu yang bersamaan. Mereka menyukai hal-hal yang serba cepat dan menghindari hal yang lambat atau berbelit-belit.
\end{abstract}

Kata Kunci: representasi Generasi Z, Novel

\section{PENDAHULUAN}

Sastra merupakan bagian dari gambaran kehidupan social yang disajikan melalui perenungan sehingga dapat hasil karya yang tercipta benar-benar citraan dari perkemangan zaman yang terjadi pada masyarakat. Di dalam karya sastra sering kita jumpai berbagai kisah yang menggambarkan kehidupan sosial masyarakat seperti politik, ekonomi sosial, budaya, dan agama. Oleh karena itu, meskipun dikatakan karya fiksi, sebuah karya sastra tidak serta-merta murni sebuah hayalan dan imajinasi. Akan tetapi, sebuah karya sastra lahir melalui tempaan pengalaman penulisnya.

Sastra senantiasa menggambarkan kehidupan dan pengalaman batin yang dialami penulisnya, sehinggga sastra sering berisikan cerita kemanusiaan, pengalaman transcendental penulisnya, kisah keluarga, dan sebagainya, bahkan tidak jarang kita jumpai karya sastra yang menceritan penderitaan yang dialami para tokoh yang diangkat dari realita sosial yang dialami oleh penulisnya. 
Karya sastra merupakan media pengungkapan ideologi penulis, baik berupa prosa, puisi dan drama. Proses penciptaan sebuah karya sastra biasanya didasari oleh sebuah konsep bersumber dari sederatan pengamatan dan pengalaman yang dialami penulis. Hasil pengamatan dan pengalaman tersebut dapat berbentuk fisik, pengalaman batin, pengalaman kehidupan social, dan pengalaman budaya. Dari unsur tersebut, secara umum dapat kita jumpai dalam bentuk karya prosa berupa novel karena novel merupakan karya sastra yang saat ini banyak digemari oleh masayarakat pembaca.

Pada era digital seperti sekarang ini, para penulis dan pembaca yang dimanjakan oleh teknologi yang mempermudah mereka untuk menghasilkan dan membaca karya sastra. Oleh karena itu, seharusnya produktivitas penulis dalam meciptakana karya sastra di era digital seperti sekarang ini seharusnya sejalan dengan minat baca generasi muda kita. Demikian pula pada masyarakat yang bersekolah, khususnya siswa masih harus dikembangkan agar benar-benar menjadi masyarakat belajar yang memiliki gairah dan kecenderungan untuk terus-menerus belajar. Minat baca itu perlu ditingkatkan karena dapat menumbuhkan kecerdasan seseorang ${ }^{[1]}$.

Masuknya gadget sangat mempengaruhi perkembangan penggunaan internet di Indonesia. Salah satu bentuk gadget yang banyak dipakai masyarakat adalah smartphone. Smartphone atau ponsel pintar adalah ponsel yang memiliki kemampuan lebih banyak dari ponsel biasa yang hanya terbatas pada telekomunikasi seperti telepon dan SMS (short message service). Smartphone memiliki tambahan fitur seperti jaringan internet internal dan eksternal seperti fitur wi-fi. Fitur tersebut membuat masyarakat menjadi semakin mudah menggunakan jaringan internet dalam kehidupan sehari-hari ${ }^{[2]}$. Bahkan ada beberapa karya sastra yang menceritakan perkembangan zaman di era digital sebagai cerminan karya sastra yang ditulis dan diciptakan oleh generasi $z$.

Generasi $Z$ adalah generasi yang mampu mengaplikasikan semua kegiatan dalam satu waktu (multi tasking) seperti: menjalankan sosial media menggunakan ponsel, browsing menggunakan PC, dan mendengarkan musik menggunakan headset. Apapun yang dilakukan kebanyakan berhubungan dengan dunia maya. Sejak kecil generasi ini sudah mengenal teknologi dan akrab dengan gadget canggih yang secara tidak langsung berpengaruh terhadap kepribadian ${ }^{[3]}$. Salah satu novel yang gambaran tokohnya berasal dari generasi $Z$ adalah novel "Taman Sunyi Sekala" Karya Aida Vyasa.

Penelitian ini bertujuan mengeksplorasi, mendeskripsikan dan mengeksplanasi wujud representasi Generasi Z yaitu fasih teknologi, sosial, dan multitasking yang terdapat dalam novel "Taman Sunyi Sekala" Karya Aida Vyasa.

Fasih Teknologi merupakan orang-orang yang termasuk pada Generasi Z adalah mereka yang disebut dengan Generasi Digital, mereka merupakan orang yang mahir dan terbiasa dengan penggunaan teknologi informasi termasuk berbagai fasilitas dan aplikasi gadget, komputer atau laptop. Sosial merupakan orang-orang yang memiliki kecenderungan waktu yang lebih lama untuk berkomunikasi dan berinteraksi dengan banyak orang diberbagai kalangan, tidak hanya teman sebaya namun juga orang lain yang lebih muda atau bahkan lebih tua melalui berbagai situs jejaring sosial seperti: Facebook, Twitter, SMS, BBM, whatsapp, dan lain sebagainya, Sedangkan Multitasking adalah Generasi Z yang terbiasa untuk melakukan berbagai aktivitas dalam satu waktu yang bersamaan. Mereka bisa membaca, berbicara, menonton, atau mendengarkan musik dalam waktu yang 
bersamaan. Mereka lebih menginginkan segala sesuatu dapat dilakukan dengan cepat, dan sangat menghindari hal-hal yang terlalu lambat atau terbelit-belit.

Berdasarkan Teori Generasi, ada lima (5) generasi yang lahir setelah perang dunia kedua dan berhubungan dengan masa kini. Don Tapscott dalam bukunya Grown Up Digital membagikan demografi penduduk kepada beberapa kelompok yang terdiri atas: Generasi Baby Boomer yaitu generasi yang merupakan orangorang yang lahir pada kurun waktu sejak tahun 1946 sampai dengan tahun 1964; Generasi $X$ yaitu generasi yang merupakan orang-orang yang lahir pada kurun waktu sejak tahun 1965 sampai dengan tahun 1980; Generasi $Y$ yaitu generasi yang merupakan orang-orang yang lahir pada kurun waktu sejak tahun 1981 sampai dengan tahun 1994; Generasi Z yaitu generasi yang merupakan orang-orang yang lahir pada kurun waktu sejak tahun 1995 sampai dengan tahun 2010; Generasi Alpha yaitu generasi yang merupakan orang-orang yang lahir pada kurun waktu sejak tahun 2011 sampai dengan tahun $2025^{[4]}$.

Selanjutnya, Generasi Z disebut juga dengan iGeneration, Generasi Net atau Generasi Internet adalah mereka yang hidup pada masa digital. Seorang Psikolog, Chou dalam bukunya yang berjudul Raising Children in Digital Era mengemukakan bahwa generasi Net adalah generasi yang lahir setelah tahun 1995, atau lebih tepatnya setelah tahun 2000. Generasi ini lahir saat internet mulai masuk dan berkembang pesat dalam kehidupan manusia. Generasi ini tidak mengenal masa saat telepon genggam belum diproduksi, saat mayoritas mainan sehari-hari masih tradisional $^{[5]}$. Lebih lanjut, Chou mengemukakan bahwa Generasi Z yang kemudian banyak dikenal dengan generasi digital merupakan generasi muda yang tumbuh dan berkembang dengan sebuah ketergantungan yang besar pada teknologi digital ${ }^{[5]}$.

Berdasarkan uraian tersebut maka tidak mengherankan jika pada sebagian besar generasi yang lahir pada kurun waktu sejak tahun 1995 sampai dengan tahun 2010 telah terampil dalam penguasaan teknologi. Mereka yang disebut Generasi Z tumbuh dan berkembang dan tumbuh sejalan dengan perkembangan media digital. Generasi ini adalah mereka yang dilahirkan dan dibesarkan pada era digital, dengan berbagai macam piranti teknologi yang terus berkembang dan semakin banyak dan canggih, seperti terciptanya berbagai perangkat keras elektronik berupa: komputer atau laptop, hand phone, iPad, MP3, MP4, dan lain sebagainya. Kemudian disusul oleh kemunculan berbagai aplikasi yang modern dan cenderung bersifat maya, seperti: SMS, BBM, Facebook, Twitter, Whatsapp, dan lain sebagainya.

Lebih lanjut dijelaskan bahwa karakteristik umum Generasi Z terdiri atas Fasih Teknologi, sosial, dan Multitasking. Fasih Teknologi adalah orang-orang yang termasuk pada Generasi Z adalah mereka yang disebut dengan Generasi Digital, mereka merupakan orang yang mahir dan terbiasa dengan penggunaan teknologi informasi termasuk berbagai fasilitas dan aplikasi komputer atau laptop. Segala informasi yang dibutuhkan dapat dengan mudah dan cepat diakses demi kepentingan hidup sehari-hari maupun kepentingan pendidikan; Sosial adalah Generasi Z yang merupakan orang-orang yang memiliki kecenderungan waktu yang lebih lama untuk berkomunikasi dan berinteraksi dengan banyak orang diberbagai kalangan, tidak hanya teman sebaya namun juga orang lain yang lebih muda atau bahkan lebih tua melalui berbagai situs jejaring sosial seperti: Facebook, Twitter, SMS, BBM, dan lain sebagainya. Bahkan tidak cukup hanya bersosialisasi dengan orang-orang atau teman satu daerah atau negara, tetapi juga lintas daerah dan lintas negara. Generasi Z ini juga lebih cenderung memiliki rasa toleransi yang tinggi terhadap perbedaan budaya dan lingkungan; dan Multitasking adalah Generasi Z terbiasa untuk melakukan berbagai aktivitas dalam satu waktu yang bersamaan. 
Mereka bisa membaca, berbicara, menonton, atau mendengarkan musik dalam waktu yang bersamaan. Mereka lebih menginginkan segala sesuatu dapat dilakukan dengan cepat, dan sangat menghindari hal-hal yang terlalu lambat atau terbelitbelit ${ }^{6]}$.

Representasi Generasi Z yang terdiri atas fasih teknologi, sosial, dan multitasking dapat kita jumpai pada berbagai karya sastra sebagai media untuk menggambarkan kondisi sosial kemasyarakatan. Salah satu novel yang merepresentasikan Generasi Z adalah novel yang berjudul "Taman Sunyi Sekala" Karya Aida Vyasa.

Novel "Taman Sunyi Sekala" Karya Aida Vyasa merupakan prosa yang berjenis novel popular. Novel populer adalah novel yang populer pada masanya dan banyak penggemarnya, khususnya pembaca di kalangan remaja. la menampilkan masalah-masalah yang aktual dan selalu menzaman, namun hanya sampai pada tingkat permukaan. Novel populer tidak menampilkan permasalahan kehidupan secara lebih intens, tidak berusaha meresapi hakikat kehidupan. Sebab, jika demikian halnya, novel populer akan menjadi berat dan berubah menjadi novel serius, dan boleh jadi akan ditinggalkan oleh pembacanya. Oleh karena itu, novel populer pada umumnya bersifat artifisial, hanya bersifat semen- tara, cepat ketinggalan zaman, dan tidak memaksa orang untuk mem- bacanya sekali lagi. Novel semacam itu biasanya cepat dilupakan orang, apalagi dengan munculnya novel-novel baru yang lebih populer pada masa sesudahnya ${ }^{[7]}$.

Lebih lanjut, masalah yang diceritakan dalam novel popular pun yang ringanringan, tetapi aktual dan menarik, yang terlihat hanya pada masalah yang "itu-itu" saja: cinta asmara (barangkali dengan sedikit berbau porno) dengan model kehidupan yang bersuasana mewah. Kisah percintaan antara pria tampan dengan wanita cantik secara umum cukup menarik, mampu membuai pembaca remaja yang memang sedang mengalami masa peka untuk itu, dan barangkali, dapat untuk sejenak melupakan kepahitan hidup yang dialaminya secara nyata ${ }^{[7]}$.

Unsur intrinsik karya sastra adalah unsur yang berkenaan dengan eksistensi sastra sebagai struktur verbal yang otonom, unsur-unsur tersebut dipaparkan sebagai berikut: (a) Tema adalah dasar atau makna suatu cerita atau novel. Secara garis besar tema dapat dibagi menjadi dua macam yaitu tema tradisional dan tema modern; (b) alur dan plot adalah struktur rangkaian kejadian dalam cerita yang disusun sebagai interelasi fungsional yang sekaligus menandai urutan bagianbagian dalam keseluruhan fiksi; (c) penokohan adalah cara pengarang menampilkan tokoh atau pelaku; (d) perwatakan dalam suatu cerita adalah pemberian sifat baik lahir maupun batin pada seorang pelaku atau tokoh yang terdapat dalam cerita; (e) suasana adalah daya pesona suatu cerita, warna dasar cerita yang membantu menegaskan maksud pengarang; (f) setting cerita adalah gambaran tempat, waktu, atau segala situasi di tempat terjadinya peristiwa; (g) sudut pandang atau yang lebih dikenal dengan point of view pada dasarnya adalah bagaimana pengarang menilai atau melihat suatu kejadian dan peristiwa; (h) gaya adalah cara khusus atau khas pengungkapan seseorang. Cara bagaimana seorang pengarang memilih tema, persoalan, meninjau peristiwa dan menceritakannya dalam sebuah cerita, itulah gaya pengarang ${ }^{[8]}$.

\section{Metodologi}

Penelitian ini merupakan penelitian deskriptif kualitatif dengan menggunakan pendekatan. Penelitian ini difokuskan pada karakteristik Generasi Z yang terdiri atas fasih teknologi, sosial dan multitasking yang terdapat dalam novel "Taman Sunyi 
Sekala" karya Aida Vyasa. Sumber data adalah tempat data itu diambil atau diperoleh. Adapun sumber data dalam penelitian ini adalah novel novel "Taman Sunyi Sekala" karya Aida Vyasa yang diterbitkan oleh Tiga Serangkai (Solo) pada tahun 2006.

Adapun langkah-langkah pengumpukan datanya, yaitu mencari dan mengumpulkan data sebagai standar, acuan dan rujukan yang dapat dijadikan pedoman dalam meneliti secara sistematis; membaca novel "Taman Sunyi Sekala" karya Aida Vyasa secara berulang-ulang; menemukan bagian-bagian yang sesuai dengan masalah yang akan diteliti, yaitu mencatat kata, kalimat, ungkapan yang dapat mendukung data; selanjutnya data yang ditemukan diklasifikasikan berdasarkan karakterisik Generasi Z yang ada pada novel "Taman Sunyi Sekala" karya Aida Vyasa.

\section{HASIL PENELITIAN DAN PEMBAHASAN \\ A. Struktur Novel Taman Sunyi Sekala Karya Aida Vyasa}

1. Tema

Tema yang diangkat dalam novel Taman Sunyi Sekala adalah menggunakan tema tingkat divine (ketuhanan) karena novel ini mencerikan tentang spiritual. Dalam novel tersebut renungan yang sangat mendalam dapat kita dapatkan dalam tema tingkat ini.

2. Alur/plot

Pada novel Taman Sunyi Sekala karya Aida Vyasa menggunakan alur maju karena menceritakan kejadian di masa kecilnya yang abu-abu yaitu perpaduan antara hitam dan putih, pertemuanya dengan Dwi sahabatnya atau Dwi yang mengenalkannya dengan buku. Setelah ia mengenal TV terlebih dahulu. Serta perkenalannya dengan dengan para pemain film dan beberapa pakar filsafat yang ia kenal lewat buku yang ia baca.

3. Penokohan dan perwatakan

Sekala dan Niskala dalam Novel ini menceritakan tentang seseorang yang bernama Sekala yang bertingkah aneh. Aneh dalam hal berbeda dengan orang-orang sebayanya. Dia hanya ingin mengenali dirinya sendiri atau hanya berbicara dan ditemani oleh dirinya sendiri. Bertanya dan menjawab pertanyaan yang ia tanyakan kepada dirinya dan mencari jawaban atas pertsnyaannya melalui buku yang ia baca.

Watak Sekala disini ramah, mudah bergaul hanya saja dia lebih sering menyendiri dan membuat dirinya menjawab pertanyaan-pertanyaan yang jawabannya itu tidak mesti dicari.

5. Latar/Setting

Pada novel ini menggunakan latar tempat yang berbeda-beda, mulai dari kamar tempat ia menulis, sekolah, kampus, masjid, dan rumah sakit. Waktu yang digambarkan dalam novel ini yaitu lebih sering pada waktu malam. Ketika sekala merasa nyaman menulis pada malam hari. Karena tidak ada yang mengganggu dan hanya ditemani oleh kesunyian ketika ingin menulis manuskrip.

Sedangkan suasana yang digambarkan dalam novel Taman Sunyi Sekala karya Aida Vyasa kadang menyenangkan dan membingungkan, kenapa dikatakan membingungkan karena terkadang pada saat membaca novel ini, pembaca kurang paham akan dari maksud ceritanya karena terkadang pada saat membaca timbul pertanyaan yang membuat pembaca berpikir akan maksudnya. 


\section{Amanat}

Amanat yang terdapat dalam novel Taman Sunyi Sekala karya Aida Vyasa yaitu mengenai tentang ketuhanan sehingga di dalam novel ini mengajarkan kita untuk lebih mengenal Tuhan dan Rasulnya. Mengajarkan kita bahwa Tuhan itu selalu ada di samping kita atau disisi kita dimanapun kita berada. Kita tidak akan pernah bisa sembunyi dari-Nya kemanapun kita sembunyi. Tuhan akan tetap melihat kita, dan takdir yang telah ia tetapkan tidak dapat kita mempungkirinya.

\section{B. Karakteristik Generasi Z dalam Novel Taman Sunyi Sekala Karya Aida Vyasa}

1. Fasih Teknologi

Orang-orang yang termasuk pada Generasi $Z$ adalah mereka yang disebut dengan Generasi Digital, mereka merupakan orang yang mahir dan terbiasa dengan penggunaan teknologi informasi termasuk berbagai fasilitas dan aplikasi komputer. Segala informasi yang dibutuhkan dapat dengan mudah dan cepat diakses demi kepentingan hidup sehari-hari maupun kepentingan pendidikan.

Berikut ini adalah kutipan tentang hal tersebut :

"aku sudah makin lihai memainkan perangkat tv seperti mengutak-atik brightness dan color contrast-nya". (TSS, 2006: 5).

Kutipan di atas merupakan salah satu karakteristik generasi Z yaitu fasih teknologi karena dalam kutipan tersebut terdapat kata makil lihai memainkan perangkat televisi. Itu mendandakan bahwa ia fasih mengguunakan teknologi.

"setapak meningkat, ketika aku, keyboard dan kesunyian disatukan maka saat itulah aku menulis" (TSS,2006: 35).

Kutipan di atas menyebutkan kata keyboard. Keyboard merupakan salah satu bagian dari perangkat teknologi yang digunakan ketika ingin menulis. Seiring perkembangan teknologi keyboard telah dirancang dengan beberapa model. Ada yang berupa perangkat keras ada pula yang berupa perangkat lunak. Kutipan diatas tidak diterangkan menggunakan perangkat lunak atau perangkat keras saya dia ingin menulis.

"aku merekamnya dalam sebuah dokumen bernama Memori dan menorehkannya diatas papyrus Microsoft" (TSS,2006: 223).

Pada kutipan di atas meunjukkan bahwa di dalam teknologi terdapat berbagi macam nama perangkat diantaranya yaitu papyrus Microsoft. Papyrus itu sendiri adalah kertas yang terbuat dari daun papyrus yang digunakan untuk menulis pada zaman dahulu. Papyrus dianggap sebagai salah satu teknologi pada zaman dahulu. Sedangkan papyrus Microsoft adalah papyrus yang telah dimasukkan dalam program Microsoft banyak untuk Windows Mac OS X. termasuk font papyrus sebagai bagian dari instalasi dasar, jadi dapat dikatakan bahwa papyrus Microsoft adalah bentuk atau huruf penulisan pada media teknologi.

"tengah malam pun aku masih saja berkutat dengan setumpuk buku diari, lalu menuliskannya secara ulang di komputer" (TSS,2006: 287). 
Kutipan di atas mendeskripsikan bagaimana Sekala yang telah mahir menggunakan teknologi, yakni ketika Sekala menulis di dalam komputer. Itu menandakan bahwa Sekala dapat menggunakan teknologi dengan fasih. Karena setelah menulis di komputer pasti akan ada yang namanya tempat penyimpanan yang biasa disebut Folder.

2. Sosial

Orang Generasi Z merupakan orang-orang yang memiliki kecenderungan waktu yang lebih lama untuk berkomunikasi dan berinteraksi dengan banyak orang diberbagai kalangan, tidak hanya teman sebaya namun juga orang lain yang lebih muda atau bahkan lebih tua melalui berbagai situs jejaring sosial.

Berikut ini adalah kutipan tentang hal tersebut:

"Internet dan koneksinya lewat Miling list, e-mail, dan mIRC adalah realitas yang muncul setelah adanya media. Inilah posrealita. Dan kematian sosial bukan lagi kematian seorang tetangga, tetapi ratapan kematian seorang tokoh maya di internet atau seorang aktor dalam sinetron" (TSS,2006: 37).

Pada kutipan di atas mendeskripsikan bahwa salah satu karakteristik generasi Z adalah sosial. Generasi Z di tandai sebagai generasi internet. Kutipan tersebut telah menyebutkan beberapa media dalam internet, hal itu tidak dapat dipungkiri bahwa melalui media itu, kita bisa saja berkenalan dengan siapapun dan dari manapun tanpa harus bertemu secara langsung dan menjalin hubungan sosial.

"Aku-Kalasekalaniskala-"ngobrol" dengan seseorang di Yahoo

Messenger. Tiba-tiba saja sebuah ID yang belum kukenal sebelumnya, masuk dan memulai sesi chat" (TSS,2006: 117).

Pada kutipan di atas menunjukkan bahwa Sekala telah melakukan hubungan sosial di internet melalui aplikasi yang benama Yahoo Messenger. Yahoo Messenger adalah sebuah aplikasi yang digunakan untuk saling berkomunikasi di dunia maya. Anak generasi $Z$ biasa menyebutnya dengan istilah chat. Menjalin hubungan di dunia maya tidak harus di batasi dengan usia. Pada kutipan tersebut tidak dijelaskan Sekala melakukan chat dengan orang lebih muda atau orang yang lebih tua.

"cintaku bersemi ketika seseorang menanyakan kabarku lewat SMS" (TSS,2006: 249).

Kutipan di atas berbeda dengan kutipan sebelumnya karena kutipan sebelumnya menggunakan Yahoo Messenger untuk melakukan komunikasi. Kutipan ini menggunakan aplikasi yang bernama SMS. Perbedaan tidak terlalu jauh hanya saja pada nama aplikasinya dan bentuk medianya. Pada Yahoo Messenger kita dapat melihat foto atau gambarnya sedangkan SMS tidak, hanya perupa pesan.

\section{Multitasking}

Orang Generasi $Z$ terbiasa untuk melakukan berbagai aktivitas dalam satu waktu yang bersamaan. Mereka bisa membaca, berbicara, menonton, atau mendengarkan musik dalam waktu yang bersamaan. Mereka lebih 
menginginkan segala sesuatu dapat dilakukan dengan cepat, dan sangat menghindari hal-hal yang terlalu lambat atau terbelit-belit.

Berikut adalah kutipan tentang Multitasking:

"aku mempunyai sebuah buku khusus yang covernya bergambar Evis Presley. Buku itu penuh dengan judul-judul film yang pernah kutunton di TV; mulai dari nama pemainnya, tahun, lokasi Syuting, juga komentarku tentang isi film itu" (TSS,2006: 6).

Kutipan di atas mendeskripsikan bahwa Sekala mampu melakukan aktivitas dalam waktu yang bersamaan yaitu dapat melihat, berpikir dan menulis. Diantaranya yaitu setelah melihat film di televisi dia menuliskannya dalam sebuah buku khusus dan tak lupa pula iya menuliskan komentar mengenai film itu.

"sound effect-nya bagus sekali sehingga imajinasiku mencuat tinggi setelah mendengar sandiwara radio itu. Sesekali aku membayngkan diriku yang berada di dalam dunia Brama Kumbara itu. Aku pun berpetualang dalam fantasi" (TSS,2006: 10).

Pada kutipan di atas mendeskripsikan adanya kegiatan yang dilakukan secara bersamaan yakni mendengarkan dan berpikir. Mendengarkan sandiwara radio sambil berpikir atau membayangkan Sekala berada pada cerita yang di dengarkan di radio, seolah-olah dia berada pada dunia cerita tersebut.

"yang kulakukan hanyalah membaca kisah Arkady dan Bazarov, lalu melukis. Begitu dan begitu saja. Yah! Aku terobsesi” (TSS,2006: 18).

Pada kutipan tersebut menjelaskan bahwa ketika membaca Sekala juga dapat melukis, dalam hal ini menandakan bahwa Sekala dapat melakukan aktivitas secara bersamaan dan tidak membuang-buang waktu untuk malakukan apa yang membuat setiap waktunya berharga atau bermanfaat bagi dirinya. Sekala sangat terobsesi dengan kisah Arkady dan Bazarov yang menceritakan tentang seseorang yang suka menyusuri perkebunan, mengamati pepohonan. Meneliti apakah akarnya menghujam normal atau abnormal.ia diam tapi benaknya sibuk, dalam artian Bazarov juga suka melakukan aktivitas secara bersamaan.

"Aku mencicipi semua hal yang populer saat itu. Aku menjadi bagian darinya. Ketika dunia gempar dengan NKOTB, MC Hammer, Vannila Ice, Kurt Cobain-nya Virvana, Tommy Page, Jason Donovan, Boy George ... sebutkan saja semuanya, aku mengenal mereka semua. Lagu apapun yang tenar saat itu, aku hafal. Lirik dan alunan nadanya pun aku bisa menggumamkannya dengan tepat" (TSS,2006: 27).

Pada kutipan di atas Sekala dapat melihat atau menonton serta mendengarkan musik, dan bahkan dapat menghafal lagu tersebut. Dapat dikatakan bahwa Multitasking telah dilakukan oleh Sekala yakni dapat melakukan aktivitas secara bersamaan. 
"Seorang gadis SMP berjilbab ternyata bisa doyan nonton TV dan dengerin radio hingga larut malam dan membuat resume atas segala film yang ia lihat, atau mendengarkan radio untuk menemaninya belajar" (TSS,2006: 27).

Kutipan di atas hampir sama dengan kutipan-kutipan sebelumnya yaitu menonton dan mendengarkan radio, membuat resume, dan atau mendengarkan radio sambil belajar itu dapat dilakukan secara bersamaan tanpa membuang-buang waktu atau terlalu berbelit-belit. Itu semua dilakukan karena menginginkan segala sesuatu yang ia lakukan harus serba cepat. Karena hal baru akan menanti keesokan harinya.

"Aku melihat TV, mencatatnya dan mengamati apa yang terjadi" (TSS,2006: 30).

Pada kutipan di atas mendeskripsikan bagaimana Sekala dapat melakukan kegiatan secara bersamaan. la telah melakukan salah satu karakteristik generasi Z yakni Multitasking.

"Dari situ aku menghargai sebuah kenangan. Mengumpulkan, melekatkan, dan memaknainya. Membuat kelipping adalah salah satu warisanku untuk orang-orang terdekat" (TSS,2006: 49).

Hampir sama dengan kutipan-kutipan sebelumnya bahwa melakukan suatu kegiatan secara bersamaan merupakan salah satu karakteristik generasi $Z$ yaitu Multitasking. Pada kutipan di atas mendeskripsikan bahwa Sekala telah membuat warisan untuk orang-orang terdekatnya, yaitu dengan mengumpulkan dan memaknai segala sesatu yang ia anggap itu penting dan menyatukannya dalam sebuah kelipping.

"Menulis tanpa fokus jelas dan sekadar membuka mulut, pikiran, dan menghentakkan jari-jari diatas keyboard" (TSS,2006: 126).

Pada kutipan di atas mendeskripsikan bahwa ketika ingin menulis, menulislah apa yang ada dalam pikiranmu, menulis ala kadarnya tanpa mengetahui hasil dan sumbangsinya kepada orang banyak. Ini adalah saat kita melangkahkan kaki dalam kehidupan, menjadi diri sendiri yang unik inilah seniman.

"Aku seharian mendengarkan musik Vangelis. Sungguh membuatku merasa dalam gelapnya teori yang diperoleh dengan mendapatkan masa kelam. Merinding seluruh tubuhku saat membayangkan seperti apa manusia jika hanya memiliki Id" (TSS,2006: 167).

Sekala ketika mendengarkan musik atau radio ia suka membayangkan dirinya berada pada saat itu. Jurang tiada dasar yang gelap itu dihadirkan oleh musik Fields of coral-nya Vangelis. Pada kutipan di atas menjelaskan bahwa dia dapat mendengarkan musik dan berpikir atau berimajinasi.

"Aku masih bersemangat untuk menulis. Membaca. Berkontemplasi" (TSS,2006: 211). 
Pada kutipan di atas mendeskripsikan bahwa Sekala dapat menulis, membaca dan berkontemplasi atau berpikir dengan penuh perhatian secara bersamaan. Karena ia ingin memaknai setiap waktu atau kejadian yang ia lalui, ia lebih memikirkan hal-hal kecil dan melupakan hal besar, Sekala memang menyukai kerumitan. Berbeda dengan orang lain yang menyukai hal-hal yang simpel, ia menyukai kerumitan, Sekala suka menyuruh pikirannya untuk bekerja rodi.

Novel Taman Sunyi Sekala karya Aida Vyasa mengandung karakteristik Generasi $\mathbf{Z}$ di dalamnya yang terdiri atas tiga bagian yaitu, fasih teknologi, sosial, dan multitasking. Karekteristik generasi $\mathbf{Z}$ didapatkan dengan cara membaca secara cermat novel tersebut.

a. Fasih Teknologi

Karakteristik generasi $Z$ yang terdapat dalam novel tersebut membuktikan kita bahwa teknologi sekarang telah menguasai manusia. Karakteristik generasi $Z$ fasih teknologi tidak dapat dipungkiri bahwa pada zaman ini semua kalangan manusia baik anak-anak, dewasa, maupun orang tua semua sudah dapat menggunakan teknologi informasi tanpa memerlukan pelatihan khusus. Mulai dari mengutak-atik fasilitas atau aplikasi yang ada dalam teknologi serta menggunakan di jejaring sosial untuk berkomunikasi dengan orang banyak. Segala sesuatu informasi dapat di peroleh dengan mudah dan cepat di akses tanpa memerlukan waktu yang lama demi kepentingan hidup sehari-hari dan kepentingan pendidikan.

Pada hasil penelitian ditemukan data kemahiran tokoh menggunakan perangkat televisi seperti mengutak-atik brightness dan color contrast-nya. Selanjutnya, pada data 2 (dua) Sekala sebagai tokoh menggunakan kata "keyboard" sebagai wujud pengetahuan sang tokoh terhadap istilah yang digunakan dalam teknologi. Pada data 3 (tiga) tokoh menggunakan perangkat teknologi yang bernama "papyrus Microsoft" sebagai bukti bahwa teknologi telah ada pada zaman saat tokoh berada. Pada data 4(empat) tokoh menggunakan salah satu alat teknologi yang bernama "komputer" yang digunakan oleh tokoh untuk menulis dan berbagai kegiatan lainnya.

b. Sosial

Karakteristik generasi Z sosial pada novel Taman Sunyi Sekala karya Aida Vyasa telah membuktkan kepada kita bahwa tidak hanya di dunia nyata orang dapat berkomunikasi atau berinteraksi kepada khalayak unum, baik itu yang lebih muda maupun yang lebih tua dari berbagai lintasan daerah, lintasan negara dan penjuru dunia, tanpa harus bertatapan muka atau saling bertemu satu sama lain hanya melalui jejaring sosial, generasi $Z$ juga cenderung memiliki rasa toleransi yang tinggi terhadap perbedaan budaya dan lingkungan.

Pada hasil penelitian telah ditemukan berbagai data yang dilakukan tokoh dalam menggunakan media teknologi seperti "Internet dan koneksinya lewat Miling list, e-mail, dan mIRC" sebagai bentuk pengetahuan sang tokoh akan perangkata teknologi dan berkomunikasi melalui dunia maya dari berbagai kalangan, pada data 2 (dua) telah ditemukan kata "Yahoo Messenger" dan kata "chat" sebagai bukti yang digunakan sang tokoh dalam malakukan interaksi dengan berbagai kalangan baik muda maupun tua serta merupakan bukti bahwa sang tokoh telah mengenal perangkat teknologi dengan baik. 
Selanjutnya pada data 3 (tiga) terdapat kata "SMS", kata tersebut merupakan salah satu perangkat teknologi untuk saling berkomunikasi dan Sekala sebagai tokoh telah membuktikan akan pengetahuan mengenai istilah yang digunakan dalam teknologi.

c. Multitasking

Karakteristik generasi Z Multitasking yang terdapat dalam novel Taman Sunyi Sekala karya Aida Vyasa telah membuktikan bahwa generasi Z memang telah memberikan pengaruh besar kepada manusia, tidak hanya berkomunikasi melalui jejaring sosial dan pengenalan tentang dunia luar, orang generasi $Z$ juga dapat melakukan berbagai kegiatan aktivitas dalam waktu yang bersamaan, mereka bisa berbicara, menonton, membaca, dan mendengarkan musik dalam waktu yang bersamaan. Mereka menyukai halhal yang serba cepat dan menghindari hal yang lambat atau berbelit-belit.

Pada hasil penelitian dalam novel Taman Sunyi Sekala karya Aida Vyasa telah ditemukan data "Buku itu penuh dengan judul-judul film yang pernah kutunton di TV; mulai dari nama pemainnya, tahun, lokasi Syuting, juga komentarku tentang isi film itu" Sekala sebagai tokoh telah membuktikan bahwa ia mampu melakukan aktivitas secara bersamaan. Pada data 2 (dua) sang tokoh telah melakukan kegiatan secara bersamaan yakni mendengar dan berpikir pada saat mendengar radio dan berimajinasi "sound effect-nya bagus sekali sehingga imajinasiku mencuat tinggi setelah mendengar sandiwara radio itu. Sesekali aku membayngkan diriku yang berada di dalam dunia Brama Kumbara itu. Aku pun berpetualang dalam fantasi"

Selanjutnya pada data 3 (tiga) terdapat kata "yang kulakukan hanyalah membaca kisah Arkady dan Bazarov, lalu melukis. Begitu dan begitu saja. Yah! Aku terobsesi" sebagai bukti sang tokoh melakukan kegiatan secara bersamaan yang juga merupakan salah satu karakteristik generasi Z. Pada data 4 (empat) terdapat kalimat yang membuktikan bahwa sang tokoh telah melaukan kegiatan atau aktivitas secara bersamaan yang merupakan salah satu karakteristik generasi Z "Aku mencicipi semua hal yang populer saat itu. Aku menjadi bagian darinya. Ketika dunia gempar dengan NKOTB, MC Hammer, Vannila Ice, Kurt Cobain-nya Virvana, Tommy Page, Jason Donovan, Boy George ... sebutkan saja semuanya, aku mengenal mereka semua. Lagu apapun yang tenar saat itu, aku hafal. Lirik dan alunan nadanya pun aku bisa menggumamkannya dengan tepat"

Kemudian pada data 5 (lima) "Seorang gadis SMP berjilbab ternyata bisa doyan nonton TV dan dengerin radio hingga larut malam dan membuat resume atas segala film yang ia lihat, atau mendengarkan radio untuk menemaninya belajar" Sekala sebagai tokoh dalam novel Taman Sunyi Sekala karya Aida Vyasa mampu melakukan kegiatan secara bersamaan sebagai bukti dari karakteristik generasi $Z$ yaitu multitasking yaitu dapat menonton dan mendengarkan radio, membuat resume, dan atau mendengarkan radio sambil belajar itu dapat dilakukan secara bersamaan tanpa membuang-buang waktu atau terlalu berbelit-belit.

Pada data 6 (enam) Sang tokoh melakuka kegiatan melihat televisi, mencatatnya dan mengamati apa yang terjadi pada tayangan di televisi, iya malakukan kegiatan secara bersamaan. Pada data 7 (tujuh) Sekala telah membuat warisan untuk orang-orang terdekatnya, yaitu dengan mengumpulkan dan memaknai segala sesatu yang ia anggap itu penting 
dan menyatukannya dalam sebuah kelipping yakni pada kutipan "Dari situ aku menghargai sebuah kenangan. Mengumpulkan, melekatkan, dan memaknainya. Membuat kelipping adalah salah satu warisanku untuk orangorang terdekat".

Selanjutnya pada data 8 (delapan) telah ditemukan data "Menulis tanpa fokus jelas dan sekadar membuka mulut, pikiran, dan menghentakkan jari-jari diatas keyboard' ketika ingin menulis, menulislah apa yang ada dalam pikiranmu, menulis ala kadarnya tanpa mengetahui hasil dan sumbangsinya kepada orang banyak. Ini adalah saat kita melangkahkan kaki dalam kehidupan, menjadi diri sendiri yang unik inilah seniman. Sekala telah melakukan kegiatan secara bersamaan yakni menulis, berpikir dan mengetik sangat mudah dilakukan oleh generasi $Z$.

Pada data 9 (sembilan) sekala sebagai tokoh dapat melakukan kegiatan secara bersamaan yakni mendegarkan musik atau radio ia suka membayangkan dirinya berada pada saat itu. Jurang tiada dasar yang gelap itu dihadirkan oleh musik Fields of coral-nya Vangelis. "Aku seharian mendengarkan musik Vangelis. Sungguh membuatku merasa dalam gelapnya teori yang diperoleh dengan mendapatkan masa kelam. Merinding seluruh tubuhku saat membayangkan seperti apa manusia jika hanya memiliki Id'. Pada kutipan di atas menjelaskan bahwa dia dapat mendengarkan musik dan berpikir atau berimajinasi.

Selanjutnya pada data 10 (sepuluh) "Aku masih bersemangat untuk menulis. Membaca. Berkontemplasi" tokoh dapat menulis, membaca dan berkontemplasi atau berpikir dengan penuh perhatian secara bersamaan. Karena ia ingin memaknai setiap waktu atau kejadian yang ia lalui, ia lebih memikirkan hal-hal kecil dan melupakan hal besar, Sekala memang menyukai kerumitan. Berbeda dengan orang lain yang menyukai hal-hal yang simpel, ia menyukai kerumitan, Sekala suka menyuruh pikirannya untuk bekerja rodi.

\section{REFERENSI}

[1] A. Akbar, "Korelasi Minat Baca Terhadap Kemampuan Menulis Cerpen di SMA" Tulura, vol. Volume 1, no. 1, pp. 42-56, Mei 2013.

[2] K. Ratih, A. Novi, and M. Titik, "Realitas Sosial Dan Representasi Fiksimini dalam Tinjauan Sosiologi Sastra," Publika Budaya, vol. 2, no. 1, pp. 50-57, 2014.

[3] Y. S. Putra, "Theoritical review: Teori perbedaan generasi," J. IIm. Makarti, vol. 9, no. $18,2017$.

[4] D. Tapscott and B. Barry, Grown up digital: How the net generation is changing your world, vol. 200. McGraw-Hill New York, 2009.

[5] H. C. Pratama, Cyber Smart Parenting: Kiat Sukses Menghadapi dan Mengasuh Generasi Digital. Visi Press, 2012.

[6] "Generasi Z dan Implikasinya terhadap Pendidikan," tentang Pendidikan, 05-Oct2012. .

[7] B. Nurgiyantoro, Teori Pengkajian Fiksi. UGM PRESS, 2018.

[8] R. Faisal, "Kajian Postmodernisme pada Novel 'Maryamah Karpov' Karya Andrea Hirata," J. Artik., vol. 7, no. 1, 2013. 